\title{
Validity of Guided Inquiry-Based Biology Practicum Guidance for Senior High School Grade XI
}

\author{
Dewi Fitrianti ${ }^{1 *}$ Lufri $^{1}$ \\ ${ }^{1}$ Biology Education of Postgraduate Program, Faculty of Natural Sciences and mathematics, Universitas Negeri \\ Padang, Indonesia \\ *Corresponding author. Email: dewifitrianti405@yahoo.com
}

\begin{abstract}
Practicum is one of learning method. One of the facilities needed in practicum is a practical guidance. One of learning approach that can support practicum activities is guided inquiry. The purpose of this study was to develop an inquiry-oriented biology practicum guide for high school grade XI semester 2 and find out the validity criteria of the practicum guide. This research was a Research and Development which used Plomp development model, which consists of three stages: preliminary research phase, development phase, and assessment phase. The validity of guided inquiry-oriented biology practice guides was obtained from the results of validation using expert validation sheet by 5 experts. The results showed that the didactic requirement got $86.43 \%$ with very valid criteria, the construction requirements got $83.13 \%$ with very valid criteria, technical requirements got $82.50 \%$ with very valid criteria, the language requirement got $84,17 \%$ with very valid criteria and the overall average of all four conditions gets $84.04 \%$ with very valid criteria. Inquiry-oriented biology practicum guide has been successfully developed with validity criteria is very valid and is expected to be a guideline for practicum guides that can help to improve students cognitive, affective and psychomotor competence.
\end{abstract}

\section{Keywords: Validity, Inquiry, Practical Guide}

\section{INTRODUCTION}

Education is needed by human because education has an important role to prepare human resources for the development of the nation and state. Education is a process of developing all aspects of cognitive, affective, and psychomotor. Improving the quality of education must always be carried out, not only regarding the curriculum and infrastructure, but also in the learning process. Students learn various kinds of subjects that show positive changes so that in the final stage they will get new skills and knowledge. Biology belongs to natural science that provides various learning experiences that can help the students understand the concepts and processes of science. The process of learning activities that can help students learn meaningfully,be done by carrying out practicum [1]. Practicum activities also increase knowledge, experience, develop scientific attitudes, so that student can understand the subject, students can get real experience so they are motivated to learn. that one of the advantages of the learning method in the form of experiment or practicum is that students have direct experience of an activity [2]. One of the practical facilities needed is a practical guide. The practical guide is a practicum facility that has been used for a long time [3]. The practicum guide can guide the students to do practicum because it contains instructions or work steps. The use of this practicum guide can help students to work continuously and directed. In addition, the practical guide should be able to guide students to develop creativity and scientific attitudes in every experiment.

Based on the results of observations at SMAN 1 Kinali,knowed that there were several obstacles in practical activities. Practicum activities still using the guidelines in the textbooks or students' worksheets are like acookbook. So that they cannot help students thinking actively and doing observations, and the implementation of the practicum is not carried out on some subject that should be practiced. [4] said that the density of subject cannot be used as an excuse for not practicing because the practicum has become a part of biology learning that must be carried out to achieve learning objectives Actually, the students like practicum activity, because it is proven that students want to study in the laboratory or field. The average value of practicum in class XI. 1 is 71, and in class XI.2 is 69 with the criteria of not achieving the Minimum Completeness Criteria (KKM) set by the school.

According to [5], guidance from teachers is still needed in learning process, so that the direction of understanding can be arranged systematically, this makes the guided inquiry approach more appropriately applied in learning. In biology learning, it is appropriate if the teacher chooses and applies the inquiry method. Because it can 
help students grow their curiosity and skills, students find various answers to questions, teachers also provide guidance especially before conducting practicum activities for students who are not used to doing scientific work steps.

The inquiry models that are more suitable for students are guided inquiry, students will be more active in collecting data to make a conclusion. Research result from [6] find that inquiry learning give positive response for students. According to [7] that inquiry learning models with experimental methods are better used in science learning. The guided inquiry approach developed in the practical guide has advantages such as: 1) students will be fully focused on the experiment subject. 2) Providing practical experiences that can form memories and skills in making direct observations. 3) Avoid the mistakes of students in making conclusions, because students directly observe the demonstration or experiment process. Laboratory inquiry generally consists of students who build and implement experimental plans and collect accurate data independently [8].

To find out the appropriateness of practicum guide that is developed, the guideline of guided inquiry-oriented biology practice must go through several stages of testing, one of which is the validity test. Validity is a standard measure that shows the accuracy and validity of an instrument, a test is said to be valid if the test measures what is being measured [9]. The test has high validity if the results are in accordance with the criteria, in the sense of having parallels between tests and criteria.A valid instrument is not only able to produce the right data but also must provide to describing the data. According to [10], valid means that the assessment has provided accurate information about the developed teaching material. Meticulous means that the measurement can describing the smallest differences between the subjects. Validity is the ability of a instrument to measure the target size [11]. Validity test aims to determine the validity of the instruments. An instrument is said to be valid if it is able to measure what is desired and can reveal data from the variables studied properly.

\section{METHOD}

This research is a research and the development. This research can produce new products that have been validated and can be used in practicum activities, and can improve student learning outcomes. The development of this guided inquiry oriented biology practice guide uses the [12] model. The Plomp development model consists of three stages: the initial investigation phase (Preliminary research), the development stage or prototype making (Development or prototype phase), and theassessment phase. The validity was assessed by experts. In the initial investigation phase, analysis of students' problems and needs, curriculum analysis, and practical guide analysis is carried out. Furthermore, at the stage of developing or making a prototype, there are several steps taken which consist of prototype I, prototype II, prototype III, and prototype IV. At the assessment stage, the practical guide test is conducted in a laboratory with the actual students. In the stage of developing and making prototypes, the practical guide is guided by research instruments. Validity test was carried out for prototype II testing by some experts. Validation of research results was carried out by five experts. Then revisions are made based on suggestions and comments from experts so that the practicum guide can be used for practicum guidelines.

Validity analysis uses practical validity data obtained from data collection instruments based on questionnaires filled by experts. Data analysis begins with determining the score for each item, determining the validation score based on Likert scale [13].

\begin{tabular}{ll} 
Score & \multicolumn{1}{c}{ Category } \\
1 & Very Disagree (STS) \\
2 & Disagree (TS) \\
3 & Agree (S) \\
4 & Very Agree (SS)
\end{tabular}

\section{Validation Sheet of Guided Inquiry-Based Practice} Guidance

\subsection{Didactic Requirements}

Didactic is a requirement that is required in the learning process to determine the true concepts in accordance with the prevailing curriculum in the school, making a systematic way, showing a good practicum guide used to measure students' competence. On the validity sheet by experts there are seven indicators assessed on didactic requirements, 1) practicum activities, 2) The purpose of practicum activities, 3) Guided inquiry oriented practice activities facilitate to understanding the concepts, 4 ) The problems presented can support students in formulating problems, 5) Formulating the problems presented can support students to find the concept of the activities to be carried out, 6) Questions that are presented support students to prove the hypotheses that have been formulated, and 7) Tables of practical activities support students to collect observations of guided inquiry oriented practicum data.

\subsection{Construction Requirement}

Constructions are requirements relating to sentence, word usage and clarity means that it can be understood by students or users. In the assessment of construction conditions there are eight indicators assessed by experts 1) Cover included all the identities of the practicum guide, 2) The practicum guide is guided inquiry oriented, 3) It has rules in the laboratory, 4) Consistent in using symbols on practicum guide, 5) The theory for each topic of practicum activities presented is systematic, 6) The practicum guide contains guided inquiry oriented, 7) The material contained in the practical guide supports practicum activities, and 8) guided inquiry-oriented biology practicum guide can encourage students to think scientifically.

\subsection{Technical requirement}

Technical requirements are requirements relating to the use of writing, images, and appearance of practicum guides developed. The indicators assessed by experts have 
three assessments, with each indicator having more specific information in the practicum guide developed. 1) Writing, there are four assessments, a) Suitability for the use of punctuation marks, b) Using a type of writing that is clearly readable and understandable, c) Using the correct writing size, d) Sentences used are in accordance with the true Indonesian language. 2) Image, there are four assessments, a) Title and description of the image in accordance with the image, b) The cover image used can convey the intended message, c) Real images, graphics, etc. are displayed clearly, d) Symbols of images displayed in each procedure of the activities that are wanted to be carried out.3) Integrity, in graphic there are four indicators that are assessed, a) Simple practicum display design, b) The color of the practical guide cover can make the reader / practitioner interested in knowing the contents of the guide practicum, c) Colors in each symbol / symbol used in practicum activities vary, and d) Suitability of the use of color composition in the practicum guide.

\subsection{Terms of Language}

The language requirement is a requirement relating to the use of language in the practicum guide developed in accordance with EBI (Indonesian Spelling). There are six indicators, 1) The language used is not ambiguous, 2) The language used is communicative, 3) The language used can develop students' thinking skills, 4) The language used is language which is good and right in accordance with the Indonesian language method, 5) The information contained in the practical guide is easy to understand, and 6) Using terms that are in accordance with the concepts that are the subject.

Validity assessment analysis in the practical guide in the form of didactic, construction, technical and language requirements based on the validity assessment sheet is carried out with the following steps:

a. Score answers with predetermined criteria.

b. Determine the highest score

Highestscore $=$ number of validators $\times$ number of indicators $\times$ maximum score

c. Determine the number of scores for each validator by adding up all the scores obtained from each indicator.

d. Determine the score obtained by adding up the scores of each validator

e. Determination of the value of validity in the following way

Validity Value $=\times 100 \%$

f. Provide an assessment of validity with the following criteria.

\begin{tabular}{|c|c|}
\hline Validity Value (\%) & Category \\
\hline $81 \%-100 \%$ & Very Valid \\
\hline $61 \%-80 \%$ & Valid \\
\hline $41 \%-60 \%$ & Quite Valid \\
\hline $21 \%-40 \%$ & Less Valid \\
\hline $0 \%-20 \%$ & Invalid \\
\hline
\end{tabular}

\section{RESULTS AND DISCUSSION}

Validation of guided inquiry-oriented biology practicum guidance was based on the points of the expert validation instrument based on the steps of developing a guided inquiry-oriented biology practicumguide, so that the guided inquiry-oriented biology practicum guide was then validated by experts. According to [14] the validator is theexperts who has the expertise in the subject to assess thepracticum guide that was developed. The

validity of guided inquiry-oriented biology practice guides includes didactic requirements, construction requirements, technical requirements, and language requirements. The validator involved in this validation process is Mr. Dr. Darmansyah, M.Pd as a technology expert, Mr. Dr. Abdurrahman, M.Pd as a linguist, Mrs. Dr. Violita, M.Si as a subject expert, Mrs. Mirdayanti, M.Si and Mrs. Erdawati, S.Pd as biology teachers. The results of the validation of guided inquiry oriented biology lab guides, validation of construct requirements, validation of technical terms, and validation of language requirements can be seen in the Appendix 1,2, 3, and 4.

The validity of the inquiry-oriented biology practice guide is obtained from the results of the validation from the expert including authorized, construction, technical and language requirements. The score of the didactic requirement validity gets $86.43 \%$ with very valid criteria, indicating that learning activities are in accordance with $\mathrm{KI}, \mathrm{KD}$, indicators and objectives of the practicum to be achieved, guided inquiry biology practice guides also facilitate the understanding of concepts and scientific thinking.

The validity of the construction requirements score is $83.13 \%$ with very valid criteria indicating that the guided inquiry-oriented biology practice guide has a guideline, the theory in accordance with the topic of the subject, and the practicum guide developed has been prepared and presented in accordance with the stages of inquiry. Practicumactivities in the practical guide have the guided inquiry syntax described by [15] are 1) Orientation, at this stage is explained steps of inquiry and practical objectives, formulating problems, formulating conclusions. 2) Formulating problems, bringing students in formulating problems and getting the right answers. With the process of finding this answer students will gain experience developing mental effort through the process of thinking. 3) Formulating a hypothesis, is seeking a temporary answer to the problem being reviewed and needs to be tested for truth. One method that can be done by the teacher to develop the ability to hypothesize students is to ask questions that encourage students to form temporary answers. 4) Collecting data is an activity to collect the information needed to test the hypothesis. The process of collecting can requires motivation in learning and potential thinking. 5) Testing the hypothesis, is determining the answers that are considered acceptable in accordance with the data or information obtained based on data collection. Testing hypotheses can develop rational thinking skills, but must be supported by data that is found and can be accounted for. 6) Formulating conclusions, the process of describing findings based on the results of testing the relevant hypotheses and data.

Validity of technical requirements score is $82.50 \%$ with very valid criteria stating that the guided inquiry- 
oriented biology practice guide hasa readable font size, the picture and caption presented in the guided inquiry oriented biology practical guide is in accordance with the material, the color composition used is in accordance with the material and the design of the biology practice guide oriented guided inquiry is simple and interesting.

The validity of language requirements gets $84.17 \%$ with very valid criteria stating that the language used has been communicative, the choice of language in the guided inquiry oriented biology practical guide has used language in accordance with EYD, the language used can develop students' thinking skills and use terms in accordance with the concept that is the subject of the material. The calculation of the validity value as a whole gets an average score $84.06 \%$ with very valid criteria, so it can be concluded that the guided inquiry-oriented biology practice guide can be used as a guideline for practicum guides that can encourage active students in practicum activities, making it easier for students in remembering and understanding the material with an inquiry orientation approach and improving students' learning competencies from cognitive, affective, and psychomotor competencies

\section{CONCLUSION}

Based on the results of the study and discussion, it can be concluded that the guided inquiry-oriented biology practicum guide has been successfully made. The practicum guide can be used as a guideline for practicum guidance in carrying out practicum activities. The practicum guide developed is very valid in terms of didactic requirements, construction requirements, technical requirements and language requirements so that the prtacticum guide that has been developed can be used in practicum activities to help students in practicum activities, understand the problems and achieve basic competencies for improve students' learning competencies from cognitive, affective, and psychomotor competence.

\section{ACKNOWLEDGMENTS}

Thanksto Mr. Prof. Dr. Lufri, MS as an advisor and always gave motivation to the writer in writing this journal.

\section{REFERENCES}

[1] Wulan, A.R. Penggunaan Assesmen Bervariasi Pada Implementasi Model Pembelajaran Berbasis Daily Life and Hand On. Makalah, (Online). 2010.pp 12-21

[2] Lufri. Strategi Pembelajaran Biologi. Padang: UNP Press. 2007.pp 55-57

[3] Kilinc, A.The Opinions of Turkish Highschool Pupils on Inquiry Based Laboratory Activities.GaziUniversity gazi Education Faculty Department of Biology Education. 2007.pp 90-94

[4] Anggriyani, Ria, Lufri, Zulyusri. Analisis Kegiatan Praktikum Biologi Kelas X Dan Xi Sman 10 Padang Tahun Pelajaran 2012/2013. Jurnal. Pascasarjana Pendidikan Biologi. Padang: Uneversitas Negeri Padang. 2013.pp 76-88
[5] Wijayanto, D., Oktavia.,danNeena Z. Pengembangan Bukupetunjuk Praktikum Kimia SMA Berbasis Inkuiri Terbimbing Pada Materi Asam Basa. Jurusan Pendidikan Kimia. 2013.pp 55-78

[6] Tompo Basman, Arifin Ahmad, Muris Muris. The Development of Discovery-Inquiry Learning Model to Reduce the Science Misconceptions of Junior High School Student. International Journal Of Environmental \& Science Education: Universitas Negeri Makasar. 2016.pp 23-45

[7] Andiasari, Liena. Penggunaan Model Inquiry dengan Metode Eksperimen dalam Pembelajaran IPA di SMPN 10 Probolinggo. Probolinggo: Jurnal Kebijakan dan Pengembangan Pendidikan. 2015.pp 23-44

[8] Wenning C.J and Wenning, R.E. 2006.A generic model for inquiry-oriented lab in postsecondary introductor physics. J Phys.Teac.Edu.3(3):24-33.

[9] Sukardi. Evaluasi Pendidikan Prinsip dan Operasionalnya. Yogyakarta: Bumi Aksara. 2008.pp 54-78

[10] Trianto. Mendesain Model Pembelajaran Inovatif Progresif. Jakarta: Kencana. 2010.pp 11-31

[11] Basworidan Siskandar. Evaluasi Belajar Berbasis Kinerja. Bandung: Karya Putra Darwati. 2012.pp 3043.

[12] Plomp, T. And Nieveen N. Part A: Educational Design Research: An Introduction. Netherland: Netherlands Institute for Curriculum Development (SLO). 2013. pp 40-56.

[13] Yusuf, M. MetodologiPenelitian. Padang: UNP Press. 2007.pp 43-56

[14] Sari, Rona Taula. Uji Validitas Modul Pembelajaran Biologi Pada Materi Sistem Reproduksi Manusia Melalui Pendekatan Konstruktivisme Untuk Kelas IX SMP. Jurnal Pendidikan Sains. Program Studi Pendidikan Biologi Universitas Bung Hatta. 2017.pp 66-76

[15] Sanjaya. Strategi Pembelajaran Berorientasi Standar Proses Pendidikan. Jakarta: Kencana Preanada Media. 2010. pp 34-55 


\section{Appendix 1}

Analysis Of Guided Inquiry-Based Biology Practice Guidance

A. Validation of Didactic Requirements

\begin{tabular}{|c|c|c|c|c|c|c|c|c|}
\hline \multirow[t]{2}{*}{ Indicator } & \multicolumn{5}{|c|}{$\begin{array}{c}\text { Validator } \\
\text { Assessment }\end{array}$} & \multirow{2}{*}{$\begin{array}{l}\text { To } \\
\text { tal }\end{array}$} & \multirow{2}{*}{$\begin{array}{l}\text { Valid } \\
\text { ity } \\
\text { Score }\end{array}$} & \multirow{2}{*}{$\begin{array}{l}\text { Criteri } \\
\quad \text { a }\end{array}$} \\
\hline & 1 & 2 & 3 & 4 & 5 & & & \\
\hline $\begin{array}{l}\text { 1. Practicum activities are in accordance with the } \\
\text { indicators to be achieved }\end{array}$ & 4 & 4 & 3 & 4 & 4 & 19 & \multirow{8}{*}{$\begin{array}{c}86.43 \\
\%\end{array}$} & \multirow{8}{*}{$\begin{array}{l}\text { Very } \\
\text { Valid }\end{array}$} \\
\hline $\begin{array}{l}\text { 2. The purpose of the practicum activities is in } \\
\text { accordance with the activities that you want to do }\end{array}$ & 4 & 4 & 3 & 4 & 3 & 18 & & \\
\hline $\begin{array}{l}\text { 3. Practicum oriented guided inquiry facilitate } \\
\text { understanding of the concept }\end{array}$ & 4 & 4 & 3 & 4 & 3 & 18 & & \\
\hline $\begin{array}{l}\text { 4. Theproblems presented can support students in } \\
\text { formulating problems }\end{array}$ & 4 & 4 & 4 & 3 & 3 & 5 & & \\
\hline $\begin{array}{l}\text { 5. Formulating the problems presented can support } \\
\text { students to find the concept of the activities to be } \\
\text { carried out }\end{array}$ & 3 & 3 & 3 & 4 & 3 & 16 & & \\
\hline $\begin{array}{l}\text { 6. The questions presented support students to prove } \\
\text { the hypothesis that has been formulated }\end{array}$ & 3 & 3 & 3 & 3 & 3 & 15 & & \\
\hline $\begin{array}{l}\text { 7. The table of practicum activities supports students } \\
\text { to collect observational data from guided inquiry- } \\
\text { oriented practicum }\end{array}$ & 3 & 4 & 3 & 3 & 3 & 16 & & \\
\hline Total & $\begin{array}{l}2 \\
5\end{array}$ & $\begin{array}{l}2 \\
6\end{array}$ & $\begin{array}{l}2 \\
2\end{array}$ & $\begin{array}{l}2 \\
6\end{array}$ & $\begin{array}{l}2 \\
2\end{array}$ & $\begin{array}{c}12 \\
1\end{array}$ & & \\
\hline
\end{tabular}

\section{Appendix 2}

\section{B. VALIDATION OF CONSTRUCT REQUIREMENTS}

\begin{tabular}{|c|c|c|c|c|c|c|c|c|}
\hline \multirow{2}{*}{ Indicator } & \multicolumn{5}{|c|}{ Validator Assessment } & \multirow{2}{*}{ Total } & \multirow{2}{*}{$\begin{array}{l}\text { Validity } \\
\text { Score }\end{array}$} & \multirow{2}{*}{ Criteria } \\
\hline & 1 & 2 & 3 & 4 & 5 & & & \\
\hline $\begin{array}{l}\text { 1. The cover that shows has included all the practicum } \\
\text { guiding identities }\end{array}$ & 3 & 4 & 3 & 4 & 4 & 18 & \multirow{9}{*}{$\mathbf{8 3 . 1 3 \%}$} & \multirow{9}{*}{$\begin{array}{l}\text { Very } \\
\text { Valid }\end{array}$} \\
\hline $\begin{array}{l}\text { 2. The practicum guide developed has been oriented towards } \\
\text { guided inquiry }\end{array}$ & 3 & 3 & 3 & 4 & 4 & 17 & & \\
\hline 3. Have regulatory rules in the laboratory & 3 & 4 & 3 & 4 & 4 & 18 & & \\
\hline 4. Consistent using symbols / symbols on the practical guide & 3 & 3 & 3 & 4 & 4 & 17 & & \\
\hline $\begin{array}{l}\text { 5. The theoretical basis for each topic of practicum activities } \\
\text { presented is systematic }\end{array}$ & 3 & 4 & 3 & 4 & 3 & 17 & & \\
\hline $\begin{array}{l}\text { 6. The practicum guide that was developed contained guided } \\
\text { inquiry orientation }\end{array}$ & 3 & 4 & 3 & 4 & 3 & 17 & & \\
\hline $\begin{array}{l}\text { 7. The material contained in the practical guide supports the } \\
\text { practicum activities that will be carried out }\end{array}$ & 3 & 4 & 3 & 3 & 4 & 17 & & \\
\hline $\begin{array}{l}\text { 8. Guided guided biology practicum guides can encourage } \\
\text { students to think scientifically }\end{array}$ & 3 & 3 & 3 & 3 & 4 & 16 & & \\
\hline Total & 24 & 25 & 24 & 30 & 30 & 133 & & \\
\hline
\end{tabular}




\section{Appendix 3.}

C. VALIDATION OF TECHNICAL TERMS

\begin{tabular}{|c|c|c|c|c|c|c|c|c|}
\hline \multirow{2}{*}{ Indicator } & \multicolumn{5}{|c|}{ Validator Assessment } & \multirow{2}{*}{ Total } & \multirow{2}{*}{$\begin{array}{c}\text { Validity } \\
\text { Score }\end{array}$} & \multirow{2}{*}{ Criteria } \\
\hline & 1 & 2 & 3 & 4 & 5 & & & \\
\hline 1.a. Compatibility of punctuation & 3 & 3 & 3 & 4 & 3 & 16 & \multirow{13}{*}{$82.50 \%$} & \multirow{13}{*}{$\begin{array}{l}\text { Very } \\
\text { Valid }\end{array}$} \\
\hline $\begin{array}{l}\text { 1.b. Using a type of writing that is clearly } \\
\text { read and understood }\end{array}$ & 3 & 3 & 3 & 4 & 3 & 16 & & \\
\hline 1.c. Use the correct writing size & 3 & 4 & 3 & 4 & 3 & 17 & & \\
\hline $\begin{array}{l}\text { 1.d.Sentences used are in accordance with } \\
\text { the good and correct Indonesian language } \\
\text { method }\end{array}$ & 3 & 3 & 3 & 3 & 4 & 16 & & \\
\hline $\begin{array}{l}\text { 2.a. Title and description of the image in } \\
\text { accordance with the image }\end{array}$ & 3 & 4 & 3 & 4 & 4 & 18 & & \\
\hline $\begin{array}{l}\text { 2.b. Cover image used to convey messages } \\
\text { on the go }\end{array}$ & 3 & 4 & 3 & 4 & 3 & 17 & & \\
\hline $\begin{array}{l}\text { 2.c. Real images, graphics, etc. are clearly } \\
\text { displayed }\end{array}$ & 3 & 4 & 3 & 3 & 3 & 16 & & \\
\hline $\begin{array}{l}\text { 2.d. Image symbols displayed on each } \\
\text { procedure of the activity that you want to } \\
\text { do }\end{array}$ & 3 & 4 & 3 & 3 & 3 & 16 & & \\
\hline 3.a. Design simple practicum guide & 3 & 3 & 3 & 4 & 3 & 16 & & \\
\hline $\begin{array}{l}\text { 3.b. The color on the practical guide cover } \\
\text { can make the reader / practitioner } \\
\text { interested in knowing the contents of the } \\
\text { practical guide }\end{array}$ & 3 & 3 & 3 & 4 & 3 & 16 & & \\
\hline $\begin{array}{l}\text { 3.c. The colors in each symbol / symbol } \\
\text { used in practicum activities vary }\end{array}$ & 3 & 4 & 3 & 4 & 4 & 18 & & \\
\hline $\begin{array}{l}\text { 3.d. Suitability of the use of color } \\
\text { composition in the practical guide }\end{array}$ & 3 & 3 & 3 & 3 & 4 & 16 & & \\
\hline Total & 36 & 42 & 36 & 44 & 40 & 198 & & \\
\hline
\end{tabular}

Appendix 4

\section{VALIDATION OF LANGUAGE REQUIREMENTS}

\begin{tabular}{|c|c|c|c|c|c|c|c|c|}
\hline \multirow{2}{*}{ Indicator } & \multicolumn{5}{|c|}{ Validator Assessment } & \multirow{2}{*}{ Total } & \multirow{2}{*}{$\begin{array}{l}\text { Validity } \\
\text { Score }\end{array}$} & \multirow{2}{*}{ Criteria } \\
\hline & 1 & 2 & 3 & 4 & 5 & & & \\
\hline $\begin{array}{l}\text { 1. The language used is not ambiguous / } \\
\text { unambiguous }\end{array}$ & 3 & 4 & 3 & 4 & 4 & 18 & \multirow{7}{*}{$84.17 \%$} & \multirow{7}{*}{$\begin{array}{l}\text { Very } \\
\text { Valid }\end{array}$} \\
\hline 2. The language used is communicative & 3 & 4 & 3 & 4 & 4 & 18 & & \\
\hline $\begin{array}{ll}\text { 3. The language used can develop } \\
\text { students' thinking skills }\end{array}$ & 3 & 3 & 3 & 4 & 3 & 16 & & \\
\hline $\begin{array}{l}\text { 4. The language used is a language that is } \\
\text { good and true according to Indonesian }\end{array}$ & 3 & 3 & 3 & 4 & 4 & 17 & & \\
\hline $\begin{array}{l}\text { 5. The information contained in the } \\
\text { practical guide is easy to understand }\end{array}$ & 3 & 3 & 3 & 3 & 3 & 15 & & \\
\hline $\begin{array}{l}\text { 6. Using terms that are in accordance } \\
\text { with the concepts that are the subject }\end{array}$ & 3 & 4 & 3 & 4 & 3 & 17 & & \\
\hline Total & 18 & 21 & 18 & 23 & 21 & 101 & & \\
\hline
\end{tabular}

